\title{
A FÖLDRAJZI TÁJAK TIPIZÁLÁSA EURÓPAI KITEKINTÉSSEL
}

\author{
CSORBA PÉTER-NAGY IMRE-CSÜLLÖG GÁBOR \\ THE CLASSIFICATION OF GEOGRAPHICAL LANDSCAPES \\ FROM A EUROPEAN PERSPECTIVE
}

\begin{abstract}
Although the classification of geographical landscapes is an important field of landscape science, an accepted method concerning how to carry it out exactly does not exist. The traditional definitions of landscape types have focused on relief, natural vegetation, and landuse, though nowadays the focus has shifted increasingly to landcover, which can be classified according to remote sensing data. The traditional school of landscape classification appeared in German and Russian geography more than a hundred years ago, as well as in other European countries with a large territiory, where practically no detailed landscape-type map existed (France for example). There is a strong incentive at the EU-level to elaborate a general landscape classification and mapping system, which would be useful when checking agricultural subsidies in the member countries.

This paper presents a European survey of the methods of landscape classification in different countries, with special attention to landscape-type maps of the neighbouring countries in the Carpathian Basin. We present here a new and detailed landscape-type map of the Northern Serbian county of Vojvodina. The landscape definitions and maps on the two sides of the Hungarian border (along the entire Hungarian border) are almost completely incompatible with each other, hence it is a necessary and very urgent professional task to elaborate a general landscape-type map of the Carpathian Basin. In the field of the historical landscape classification of the Carpathian Basin the situation is better, as we have a map referring to the landscape from approximately $900 \mathrm{AD}$ and another one from the period between 1200 and 1600 AD. An important conclusion of the paper is that traditional descriptions of landscape types are suitable for a general survey but not for practical purposes such as landscape planning, landscape protection, or tourism geography. For these purposes more elaborate special classification methods are a must.
\end{abstract}

Keywords: landscape classification, indicators for classification, limits of general definitions, regional differences of classification

\section{Bevezetés}

Bár két tökéletesen azonos felépítésű és megjelenésű táj nincs, vannak azonban feltűnő vagy kevésbé látványos hasonlóságok az egyes tájak között. A tájföldrajzi kutatások egyik fontos szintetizáló ága, a tájtipizálás ezen hasonlóságok alapján csoportosítja a tájakat. A tájtipizálásnak az a gyakorlati jelentősége, hogy azonos csoportba tartozó tájak hasonló potenciális adottságokkal rendelkeznek, hasonló tájmúködési zavarok léphetnek fel (pl. hasonlók a tájérzékenység kritikus pontjai) és tájtervezési szempontból is hasonló problémákkal, területhasználati konfliktusokkal kell számolni.

Az elméleti és gyakorlati indokoltság ellenére a tájtipizálásnak máig nem alakult ki egységes nemzetközi módszertana. Ennek egyik oka, hogy a típusdefiníciókban szereplő természetes tájalkotó tényezők (földtani alapok, domborzat, éghajlat, stb.) maguk is földrajzi térségenként eltérō típusmeghatározó erővel rendelkeznek, ezáltal van, ahol az egyes tájtípusok például a kőzetminőség, máshol inkább az éghajlati adottságok változása alapján jönnek létre. A másik ok, hogy az emberi tevékenység egyre erősebben alakítja a tájakat, ezáltal vannak, akik a tipizálási rendszert már nem a természetes tájalkotó tényezőkre, inkább a területhasználat különbségeire alapozzák. Lényegében ezen a nyomon - jelentős mértékben a távérzékelési adatokra támaszkodva - indult el néhány európai uniós kezde- 
ményezés is, a tájakat a felszínfedettség szerint tipizálva. Az egységes európai metodika kidolgozását az is lefékezte, hogy az utóbbi évtizedben angol kezdeményezésre a hagyományos földrajzi tájtipizálás helyett a tájkarakter vizsgálata került a szakmai érdeklódés középpontjába. A témával foglalkozók jó része kutatásait a vizuális tájértékelésre koncentrálta, sürgetőbbnek, aktuálisabbnak érezvén, hogy megbízható szempontrendszert dolgozzon ki pl. az idegenforgalom által igényelt tájattraktivitás minősítése számára.

Magyarország esetében különösen zavaró tény, hogy mivel a múlt század közepétől a Kárpát-medence politikai megosztottságának köszönhetően - a talaj vagy a vegetáció térképezéséhez hasonlóan - a tájtipizálás nemzeti keretek között fejlődött, ezáltal az országhatárok mentén ma csak nagy nehézség árán lehet úgy-ahogy összeilleszteni a szomszédos országok tájtípustérképeit. Egy Kárpát-medencei tájtípustérképet még az új nemzeti atlasz számára sem sikerült elkészíteni. Valamivel jobb a helyzet a tájtipizálás egy sajátos ága, a történelmi múltra vonatkozó tájtipizálás tekintetében, hiszen a honfoglalás korára, újabban a késő középkorra nézve készült egész Kárpát-medencét ábrázoló térkép.

Az alábbi tanulmány széles, bár - terjedelmi korlátok, valamint az illusztrációként szolgáló térképek heterogén minősége miatt - nem teljes körú áttekintést kíván adni a tájtipológia európai és hazai eredményeiről, annak történeti változásairól és a jelenlegi tendenciákról.

\section{Európai körkép a tájtipizálásról}

A tájtipizálás tekintetében nincs általánosan elfogadott, nemzetközi módszer. A típusalkotásban a 19. század végtől a német geográfusok játszottak kezdeményező szerepet, s több közép-európai országban azóta is kimutatható ennek hatása. A nyugat- és a középeurópai természeti adottságoktól lényegesen eltéró, zonális kifejlődésú éghajlati, talajtani és biogeográfiai elrendeződés egyértelmú dominanciája is hozzájárulhatott ahhoz, hogy az orosz tájkutatás más utat járt be. Több kelet-európai országban ma is ez a tájtipológia alapja. És vannak olyan jelentős kiterjedésú országok (pl. Olaszország), ahol a 15-20 éve kezdődött európai uniós módszertani megújulás előtt nem is volt nemzeti indíttatású tájtipizálás.

A földrajzi tájtipológia történetében tehát vitathatatlanul a németeké az elsőség. A rendkívül erős osztályozási törekvés csúcspontját az 1960-as, 1970-es években - sajátos módon - a kelet-német geográfia képviselte (NEEF, E. 1963, HAASE, G. 1976, MANNSFELD, K. 1984). A rendkívül alapos, hosszan tartó geomorfológiai, talajtani, hidrológiai, mikroklimatológiai és biogeográfiai terepi mérések, megfigyelések, sőt kísérletek segítségével kiépített hierarchikus rendszer lehatolt a néhány 100 méteres tájfoltok, az ún. „mikrogeochorák” szintjéig (1. ábra). A hagyományos természetföldrajzi megközelítésre az 1980-as évektől kezdve Németországban is egyre inkább rányomta bélyegét az ökológiai szemlélet, s a korábbi felmérések geotopjait ökotoppá fejlesztve a németek a kibontakozó tájökológiai kutatási irányzatban is tevékeny szerepet játszottak. A részletes terepi adatbázis birtokában gyorsan kidolgozták az országostól a helyi szintig terjedő teljes ökológiai tájtipológiai vertikum térképeit. Az egykori NDK lipcsei, hallei kutatóintézetei az egyesült Németországban is meg tudták tartani szakmai vezető szerepüket (HAAREN, von CH.-Albert, CH. 2016).

A gyakorlatias, ökológiai szemlélet szembeötlő jele, hogy a térképeken önálló kategóriaként megjelennek a beépített, urbanizálódott, valamint a külszíni bányászat által elfoglalt területek (2.ábra). Ilyen tájtípusnak a korábbi, természetföldrajzi tipológiában szinte nyomát sem találjuk. Ugyanakkor a térkép alapvetően a talajban található nedvesség mozgásának iránya, intenzitása, illetve ehhez kapcsolódóan a tápanyagmozgás dinamikája alapján 


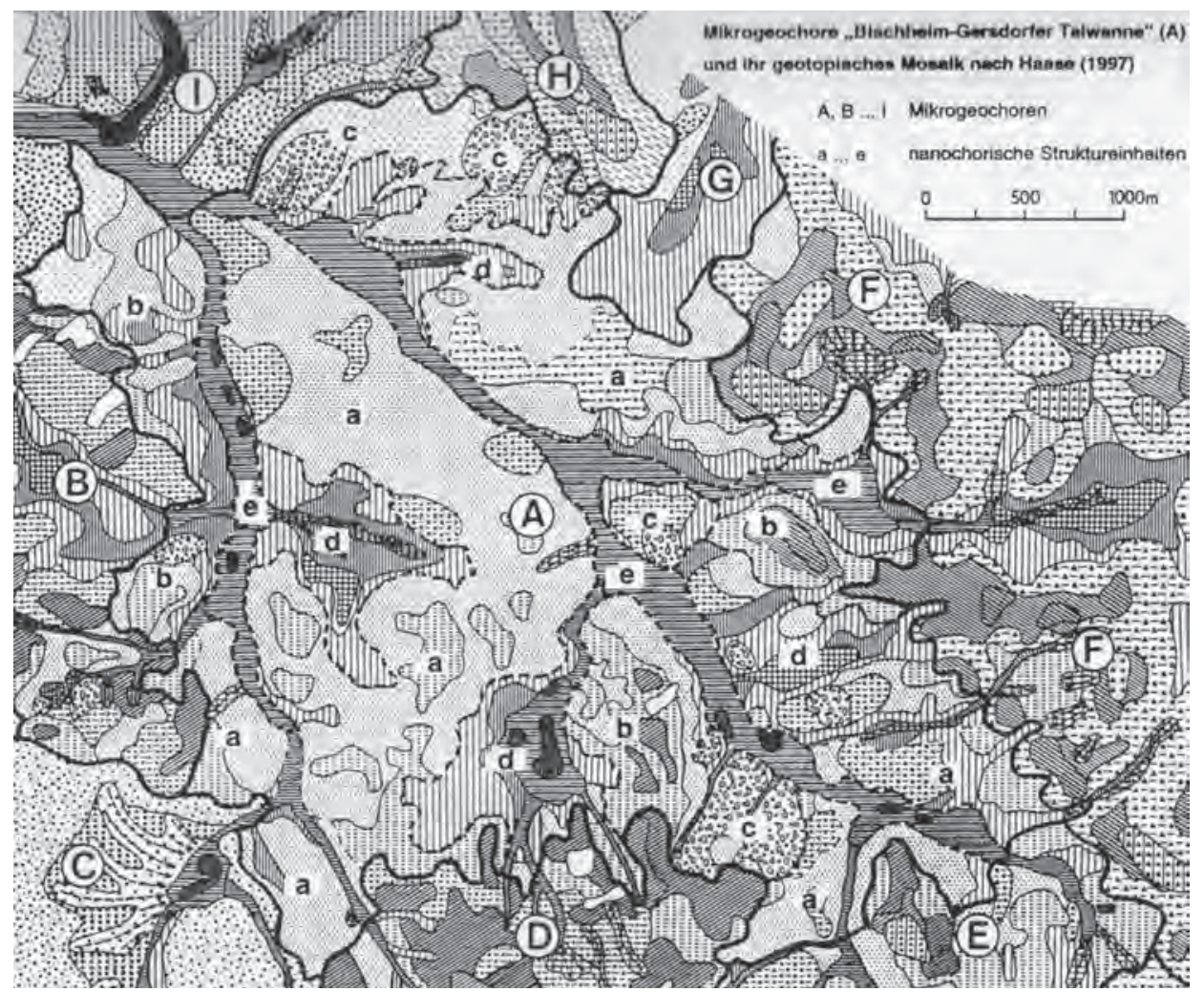

1. ábra Mikrogeochorikus térkép részlete (HAASE, G. 1997)

Figure 1 Detail of a microgeochorical map (HAASE, G. 1997)

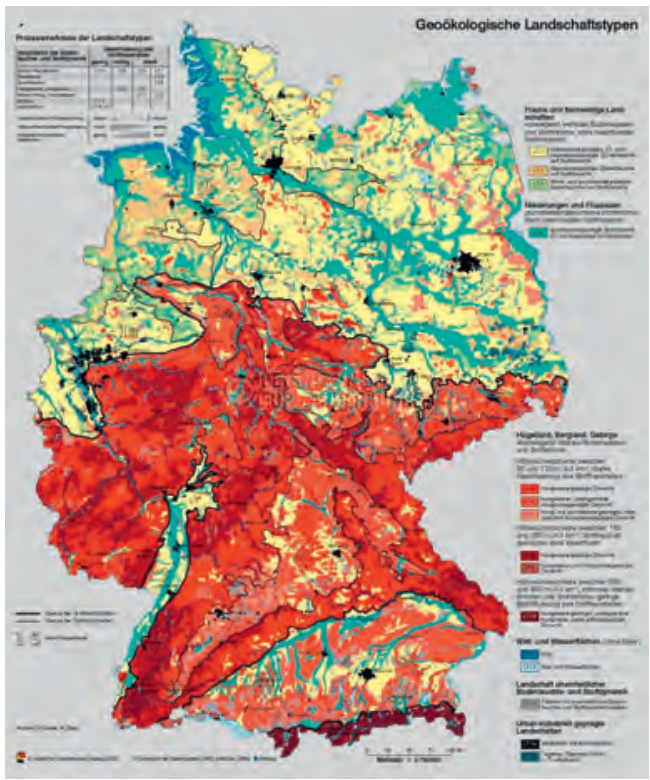

2. ábra Németország geoökológiai tájtípusai (BURAK, A.-Zepp, H. 2003; Németország Nemzeti Atlasza) Figure 2 Geoecological landscape types of Germany (BURAK, A.-ZEPP, H. 2003; National Atlas of Germany) 
osztályozza a tájakat. A fenti tulajdonságokat elsősorban a domborzat és a talajfedettség jellege (beépítettség, erdők, szántóföldek stb.) irányítja. A domborzati faktort számítógépes modellezéssel a tengerszint feletti magasság és a reliefkülönbség alapján kategorizálták.

Tudománytörténeti kapcsolatok miatt a német tájföldrajzi iskolához kötődő országok tájföldrajzi tipológiai rendszere egymással sok hasonlóságot mutat. Ehhez a csoporthoz tartozik Magyarország, Csehország, Szlovákia, Szlovénia és Lengyelország, illetve - kicsit eltéró nevezéktannal - Belgium, Svájc, Észtország, Svédország és Finnország is.

A belga geográfia lazábban kötődik a német tájföldrajzi iskola metodikai fogásaihoz, de hasonlóság pl. a földtani alapok és a hidrológiai alaptulajdonság beépítése a tájtípus nevébe. Az eddigiekhez képest a belgiumi módszer erôsen épít arra, hogy az ország hagyományos tájnevei egyúttal kifejezik, mindenki által ismert módon felidézik a táj megjelenését, jellegét is. Így aztán Flandria, illetve Vallónia tradicionális tájtípusainak térképén a megnevezések többsége egyszerúen az adott táj tulajdonneve; pl. Kempenland, Maasland, Brabanti-Ardennek, illetve Meuse, Fagne stb. A természeti adottságokból adódó különbséget csak néhány esetben jelzik: pl. Belső-Flandria sík, homokos vidéke, illetve BelsőFlandria dombvidéki, agyagos tája. A tájtipizálás modern - célirányosan alkalmazott irányzatai között fontos szerepet tölt be a genti egyetem MARC ANTROP nevével fémjelezhető iskolája (vö. ANTROP, M. et al. 2004), amelynek erôssége, hogy a komoly számítógépes háttér ellenére ragaszkodnak a közvetlen, rendszeres terepi megfigyeléséhez. Az újabb tájtípustérképek már Belgiumban is egészen eltávolodnak a hagyományos természetföldrajzi alapoktól, és a tipológia vezérelve sokkal inkább a földhasználat módja. A 3.ábrán látható, hogy - nyilván a méretarány tól is függően - van a tipológiai rendszernek egy általánosítóbb változata, valamint egy részletesebb is, ahol külön-külön megjelenhet például a 18-féle mezőgazdasági vagy a 14-féle erdészeti tájtípus.

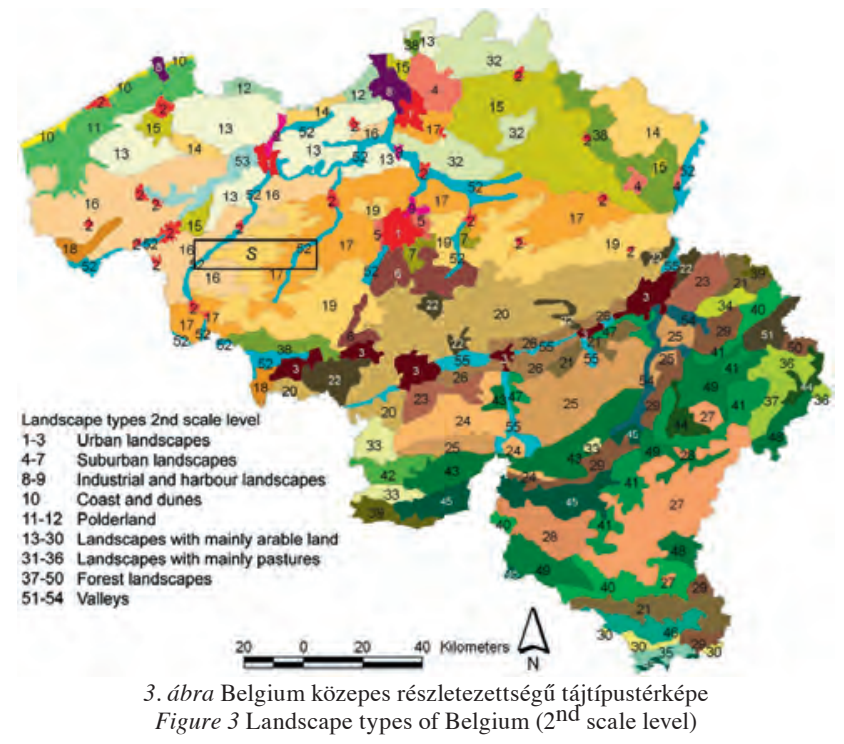

Svájc 2016-ban kiadott Nemzeti Atlaszában a tájtipológiának vezéralakítója egyértelmúen a domborzat. A nagy tájegységeken - Jura-hegység, Mittelland és Alpok - belül különítettek el völgyi és medence jellegú, hegylábi dombvidékeket, platószerúen kiemelt fennsíkokat, illetve magashegységi tájtípust. A morfológiai kategorizálás azonban nem 
következetes abban az értelemben, hogy van néhány felszínfedettség, vagy geológiai adottság alapján elkülönített tájtípus is, ilyenek pl. a Táblás-Jura erdő fedte dombvidéke, magashegységi sziklagyep, az Északi-Alpok mészkővidéke, kristályos kőzetből felépülő alpesi táj stb. A beépítettség szintén több esetben tájmeghatározó tényező, sőt a tipológia megkülönböztet városias és települési tájtípust. Egészen ritka eset a tájtipológiában, hogy egy éghajlati vonás legyen tájtípusképző erő; a „csapadékban gazdag alpesi hegyvidéki táj" ilyen kivétel.

Ahogy Svájcban a tengerszint feletti magasság, úgy a skandináv országokban az észak felé haladva megjelenő éghajlatváltozás eredményez tájváltozást. Nem véletlen, hogy a skandináv országok tájtipológiájában az éghajlat alapján képeznek nagytáji egységeket, azon belül viszont a domborzat és a földhasználat a finomabb csoportosítás alapja. Mivel Svédország (és ugyanígy Finnország is) a szántóföldi múvelhetőség határán fekvő ország, a tájak vizuális megjelenését nagyban meghatározza, hogy abban az erdő, a legeló vagy a szántóföldek látványa meghatározó-e. Mivel a hegyvidéket többnyire erdő fedi, az említett szerény változatosság inkább csak a hegylábi és a tengerparti síksági tájakra vonatkozik (JANSSON, U. et al. 2004).

A német tájföldrajzi iskolához módszertanilag az orosz állt a legközelebb. Az orosz talajtani és növényzeti kutatások korán felfedezték és feltérképezték a Kelet-európaisíkságon olyannyira feltűnő életföldrajzi övezetességet. Az itt található országokban - Litvánia, Fehéroroszország, Ukrajna - ma is ehhez a két tájalkotó tényezőhöz igazodik a tájtipizálás. A tájtípusok elnevezésében markánsan jelen van a talaj-növényzet kapcsolat, a máshol fó meghatározó tájtényezőnek, a domborzatnak itt kisebb a tájdifferenciáló hatása. Egyébként pedig a német iskolához hasonlóan a tájtípusok megnevezésében igyekeznek minden tájalkotó tényezôt érinteni. Ennek a biogeográfiai-talajtani megközelítésnek iskolateremtő példája volt az ún. „,szerkezet-dinamikus”módszer alkalmazása. Képviselői az 1960-as években egy szinte minden természetföldrajzi kutatási előzmény nélküli területen, a sztyeppzóna dél-szibériai részén folytattak igen alapos tájföldrajzi felméréseket. Ezek az emberi hatástól még sok helyen alig érintett tájak alkalmasak voltak a természetes táji anyag- és energiafolyamatok megfigyelésére, a természetes tájfejlődés egyes stádiumainak elkülönítésére, ezáltal az időbeli szakaszok, ún. epifáciesek leírására (SzOCSAVA, V.B. 1970).

Ellentétben a fent bemutatott orosz tájtipizálással a brit-skót földrajzi módszertan feltûnő módon kerüli a biogeográfiai és a talajtani megközelítést és inkább a kőzettani alapok, az éghajlat és a domborzat alapján képez bizonyos tájcsoportokat. Ennek oka a még a skandinávnál is szegényesebb növénytani változatosság, és a szintén csekély talajtani diverzitás. Skóciában pl. a tájképileg feltűnő erdők többnyire csak a szélvédett völgyekben tudnak megélni, a növényfedettség gyakorlatilag a fenyéresek és a kopár sziklafelszínek mozaikjára szorítkozik. A tájtipizálás sajátos nagy-britanniai vonása, hogy itt veszik leginkább figyelembe a tengerpartok tájtípust befolyásoló hatását, és a „landscape” mellett számos „,seascape” típust is leírnak, aszerint, hogy pl. lapos vagy meredek-e a part, sűrűn, vagy ritkásan vannak-e szigetek a part mentén stb. Az angolok a tengerparti tájak tipizálásához 2012-ben külön útmutatót adtak ki An approach to seascape character assessment címmel (Natural England, 2012). A brit-skót tájkutatás azonban a nemzetközi szakirodalomban inkább az 1990-es évek közepétől beindult tájkarakter-értékelő tudományos program (SwANwiCK, C. et al. 2002) révén vált közismertté. A táj arculatának kifejezésére használt nevezéktanban a geográfiai oldalt következetesen csak a nagy domborzati formák képviselik, mint felföld (highland), síkság (lowland) vagy fennsík (upland) stb. A talaj, a hidrológiai jelleg, vagy a természetes növényzet általában nem szerepel a meghatározásokban. 
Különös módon a francia tájkutatás esetében a földrajzi háttérnek - pl. a felszínalaktannak - soha nem volt olyan meghatározó szerepe, mint pl. a németeknél, vagy épp nálunk. Így a francia tájak tipizálása sokkal jobban tükrözi a társadalmi, gazdasági és újabban az esztétikai szempontokat (TROCHET, J-R. 2004). Országos szinten pl. BRUNET, R. 19 tájtípus-elnevezésében a nagyvonalú domborzati kategorizálás (síkság, dombság, hegység) után inkább a felszínborítási meghatározások sorakoznak, mint pl. jellegzetes Bretagne-i sövénytáj, a bocage, vagy a szőlőterületek, a nagyparcellás szántóföldek, illetve az erdők, a száraz mediterrán macchia bozótosok stb. (4.ábra).

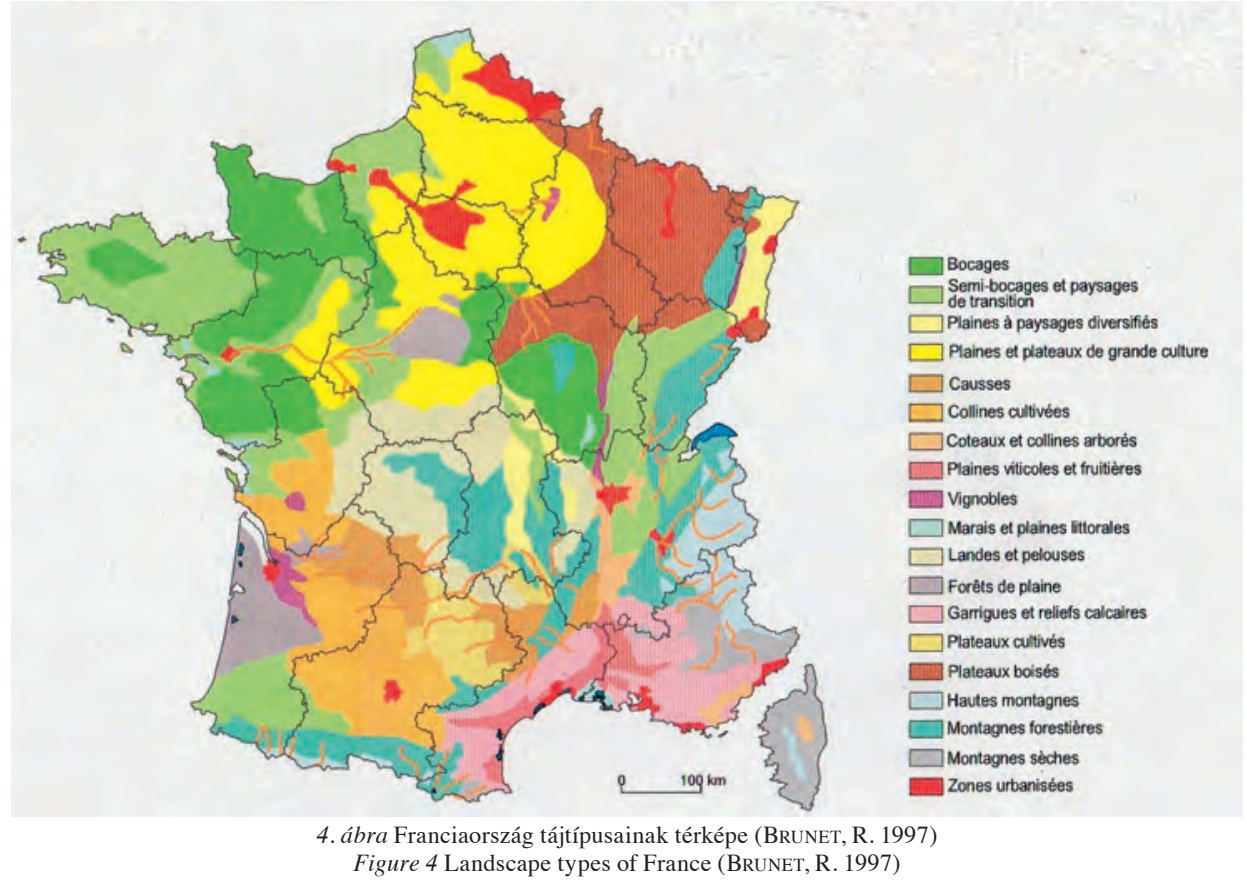

Nem lehet csodálkozni azon, hogy a holland földrajzi atlaszban a tájtípusok már évtizedekkel ezelőtt csak a kultúrtájak címszó alatt jelentek meg (De Grote Bosatlas 1988: Cultuurlandschappen). Hollandia területén régóta már szinte kizárólag „embercsinálta” tájak sorakoznak. A mesterséges szárazföld polderek képviselte típusa, illetve a súrú csatornahálózattal ellátott táj jellegében alig tér el egymástól, s némi változatosságot csak a nagyobb folyókat, torkolatvidékeket kísérő tájak képviselnek. Ezekhez képest viszonylag markáns különbséget tapasztalhatunk a tengerparti dûnevidék, illetve a magasabb ármentes jégkorszaki fenékmoréna alkotta ún. geestvidék tájtípusa között.

\section{Kísérletek az egységes európai tájtipizálási rendszer kialakítására}

Az Európai Unió bővülésével az 1990-es évektől egyre sürgetőbb igény jelentkezett arra, hogy a különféle uniós területfejlesztési, vidékfejlesztési, környezetvédelmi programok kiírásához, tartalmi kidolgozásához, majd az elnyert pályázatok eredményeinek értékeléséhez, ellenőrzéséhez rendelkezésre álljon egy egységes tájminoosités. 
Az uniós javaslatok kezdetben igen egyszerű kategóriákat tartalmaztak, amelyek szinte kizárólag az aktuális területhasználat jellegét helyezték a típusmegnevezések központjába. Ezek a térképek az ürfelvételek alapján készült CORINE (Coordination of Information on the Environment) környezeti információs rendszer adatbázisára épültek. Igy pl. az Európai Környezetvédelmi Ügynökség (European Environment Agency, EEA) néhány évenként megújított térképein városi beépítésú, intenzív szántóföldi, vidéki legelő-mozaikos térségek, erdőfedte tájak és természetközeli gyepes térségek szerepeltek (5. ábra). A digitális pixeleket nem vonták össze tájegységekké, tehát igazi tipizálásról nincs szó, bár a térkép megnevezése egyértelmúen tájtípusokról szól és a pixelek persze foltokká állnak össze.

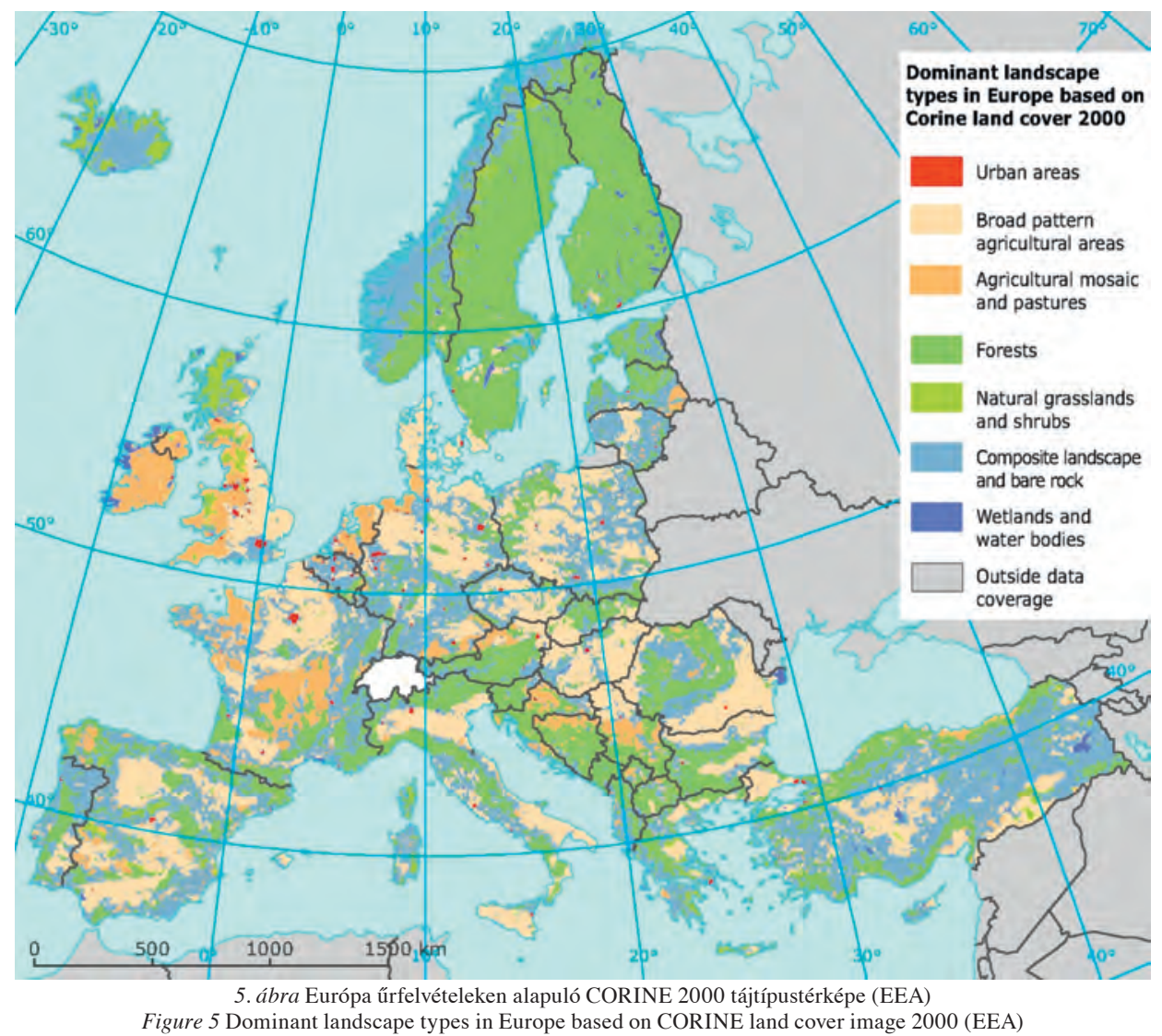

Jelentős ismertségre tett szert egy holland szakértő, MeEus, J. H. A. (1995) által javasolt európai tájtipológiai rendszer 8 fótípussal (6. ábra). Részben az éghajlati és életföldrajzi jelleg (pl. tundra, sztyepp), másrészt a domborzat (pl. fennsíkok, hegyvidékek), harmadrészt pedig földhasználati szerkezet, hangsúlyosan a történelmi tájtípusok alapján (pl. a francia sövénytáj, a bocage, a közép-olasz vegyes gazdálkodási szerkezet, a coltura promiscua, vagy az Ibériai-félsziget egyes részein jellegzetes kettős földhasználatú - olajfák alatt gabonatermelés, vagy legeltetó állattartás - ún. dehesa). A nyolc fótípuson belül további típusokat különített el, ezek egyike a bennünket is érintő „,puszta”, ami - valljuk be a térképen feltúnően nagy foltot fed le. 


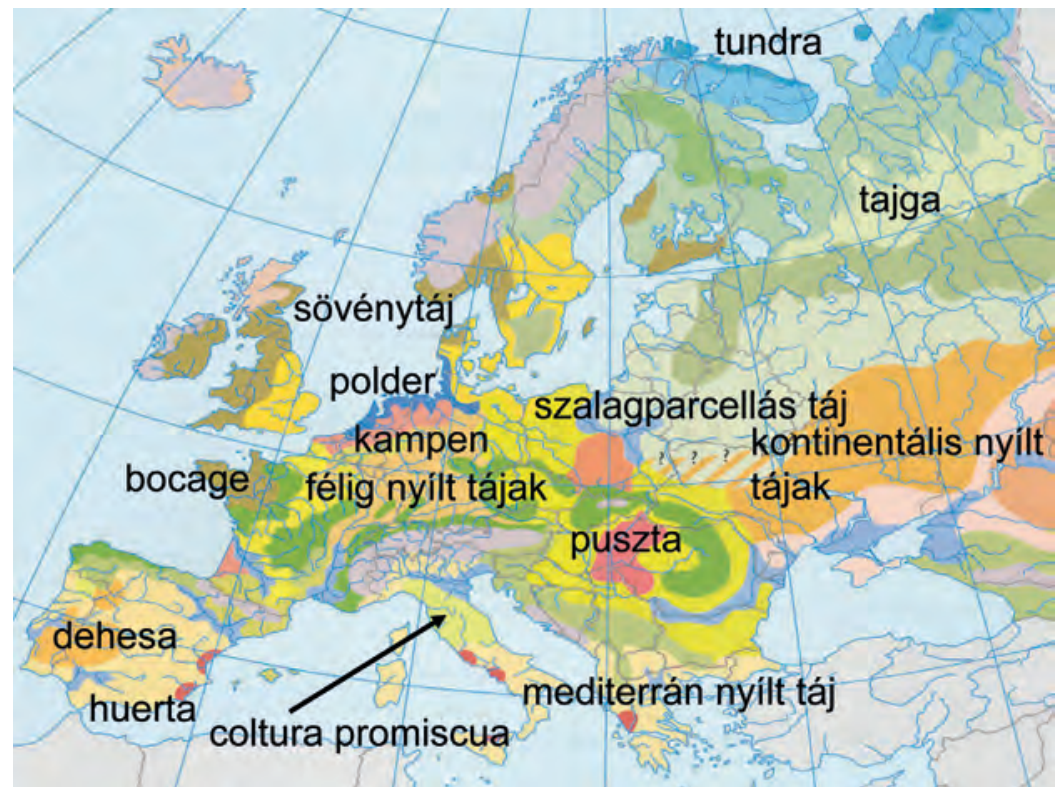

6. ábra Európa tájtípustérképe (MeEus, J. H. A. 1995 alapján szerk. CsorbA P. 2013)

Figure 6 Landscape types of Europe (according to MeEus, J. H. A. 1995, modified by Csorba, P. 2013)

\section{A magyar földrajz tájtipizálás-történeti lépései és legújabb eredményei}

Magyarország első tájtípustérképét STRÖMPL GÁBOR készítette, 1922-ben (7. ábra). STRÖMPL szakmai gyökerei ugyan szorosan kapcsolódtak a klasszikus LóCZY LAJOS - CHOLNOKY JENŐ-féle geológiai-geomorfológiai iskola hagyományaihoz, ugyanakkor az

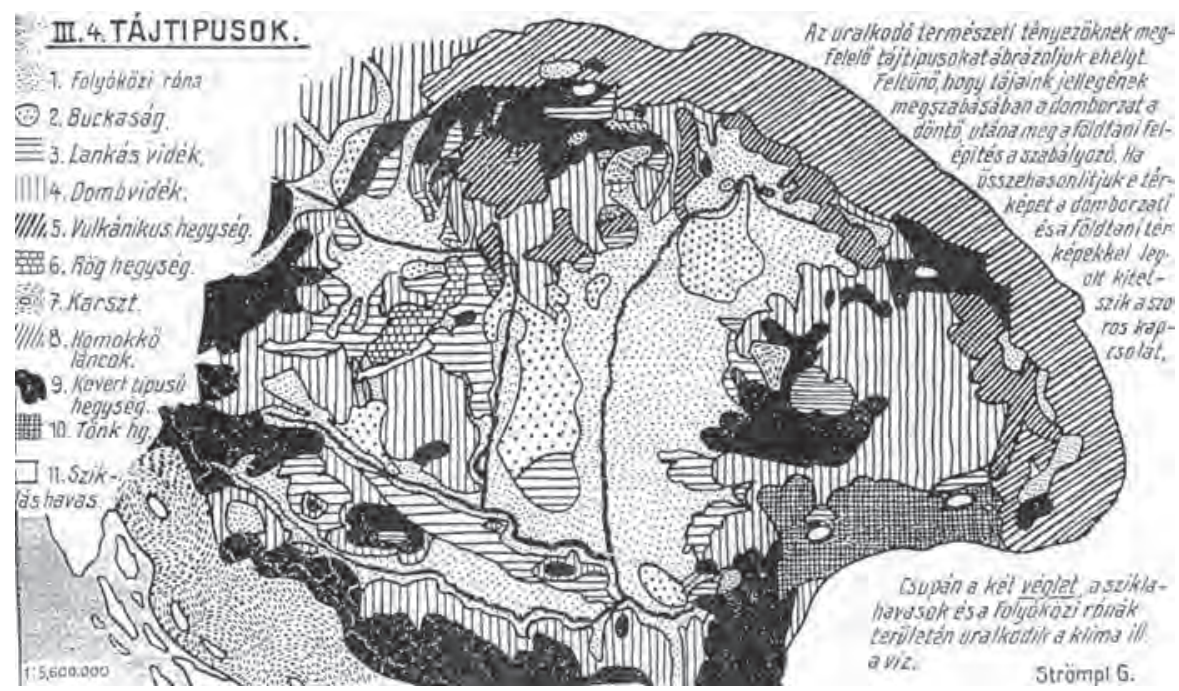

7. ábra A történelmi Magyarország tájtípustérképe (STRÖMPL G. 1922)

Figure 7 Landscape types map of historical Hungary (STRÖMPL, G. 1922) 
1920-as években az ő tájfelfogása képviselte leginkább a földrajzi táj kettősségét, annak egyensúlyban lévő természeti és társadalmi meghatározottságát. Erős természetföldrajzi alapokon álló tájrajzaiban jelentős szerepet játszott az emberi területhasználat, a településhálózat bemutatása, s ebben a kiegyensúlyozott tájfelfogásban kimutatható másik mesterének, TELEKI PÁLnak a hatása is. A megszokott fontossági hierarchiától eltérōen a folyó menti ártereken a vízrajzi tájkomponensnek van kiemelkedő tájformáló hatása. A térkép nevezéktanában érdekes vonás, hogy STRÖMPL is észrevette a magashegységek csúcsrégiójában a „sziklás havas” típus éghajlat általi meghatározottságát (lásd a térkép jobb alsó sarkában lévő megjegyzést). Ezt a különleges esetet Svájc, illetve Skandinávia kapcsán is említettük már.

A hazai tájtipizálás következő korszakában, az 1960-as években látványosan megerősödött az elsôsorban PÉCSI MÁRTON nevével összefonódott geomorfológiai iskola felfogása. Az 1971-ben megjelent tájtípustérkép (PÉCSI M. -SOMOGYI S. - JAKUCS P.) típusmegjelölései, illetve területi egységei erósen igazodnak az ország geomorfológiai térképeihez (8.ábra). A hazai tájtipizálás homogén (táj)ökológiai egységekben gondolkodott, hierarchikus tagolású, a természetes tájalkotó tényezők között a domborzatnak van kiemelt szerepe, de a típusalkotás fajsúlyos szempontja lett a területhasznosítás jellege is.

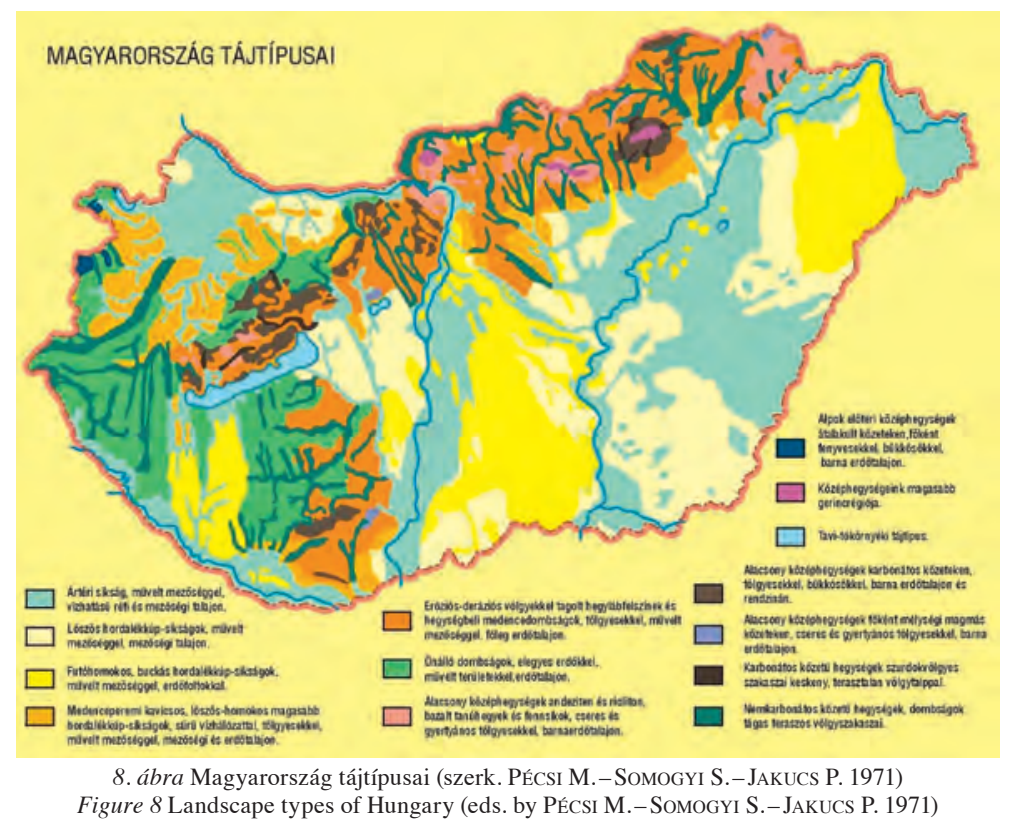

Lényegében ebben a szellemben készült el hazánk 1989-ben megjelent (második) nemzeti atlaszában szereplő tájtípustérkép is (szerk. JAKUCS P. - KERESZTESI Z. - MAROSI S. - PÉCSI M. - Somogyi S.). Az ott alkalmazott rend szerint a térképen szereplő tájtípusok megnevezése először a hazai tájak éghajlattani besorolására utal (mérsékelten kontinentális), majd négy fôtípuscsoportot képez: síksági, uralkodóan mezőgazdasági hasznosítású; dombsági, uralkodóan mező-, illetve erdőgazdasági, lokálisan ipari jellegú; középhegységi erdős; valamint néhány sajátos jellegú - völgyi és tavi, tó környéki - tájtípusokat.

A tájtípusok meghatározásában tehát egy éghajlattani pozicionálást követően nagyon erős típusképző erôt képvisel a domborzat tipizálása, viszonylag következetesen végigviszi 
a talajtani besorolást, és mérsékelten részletező differenciálás olvasható a földhasználat, illetve a hidrológiai tájalkotó elemek tekintetében. A szóban forgó tájtípustérkép elterjedését és használatát gátolta, hogy a típusdefiníciók igen hosszúak, a hasznosításra utaló fogalmak nem alkotnak következetes rendszert, továbbá helyenként nehezen összemérhető léptékú és eredetú (genetikájú) domborzati egységek szerepelnek.

A hazai és a nemzetközi tapasztalatok alapján az ezredforduló után a geográfusok arra meggyőződésre jutottak, hogy a természeti környezet nagyfokú átalakítottsága miatt a döntően természeti adottságokra alapozó hagyományos tájtipizálás ma már nem felel meg a gyakorlati igényeknek. Egy általános, elvileg „mindenre használható” tájtipológiai térkép nem nyújt kellő támpontot a tájtervezési, tájvédelmi célok számára. Más tényezők határozzák meg ugyanis a tájak típusait, ha azokat múködési, esztétikai, vagy földhasználati, területtervezési célból készítjük el.

\section{Korszerú hazai földrajzi tájtipizálás}

A fentiek miatt a 2018-ben megjelent új nemzeti atlasz (KocSIs K. 2018) számára MEzősI GÁBOR és BATA TEODÓRA többféle tájtípustérképet készített. Az egyik megközelítés a táji egységek kialakulása (genetikája), a másik az egységek múködése, a harmadik pedig a táj használatának szempontjából különített el tájtípusokat. Az egyes táji egységek kialakulása, azaz genetikája szerinti tájtípusokat a természetes tájkialakulásban döntó szerepet játszó domborzati, litológiai (talajképző kőzet), valamint a talajtani ismérvek alapján alkották meg (9. ábra). Fontos még a vízzel kapcsolatos információ, ezt azonban áttételesen a talaj és a domborzat tartalmazza. A paramétereket az ún. természetes töréspontos statisztikai módszerrel rendezték csoportokba, majd a három alaptérkép adataiból súlyozás nélküli

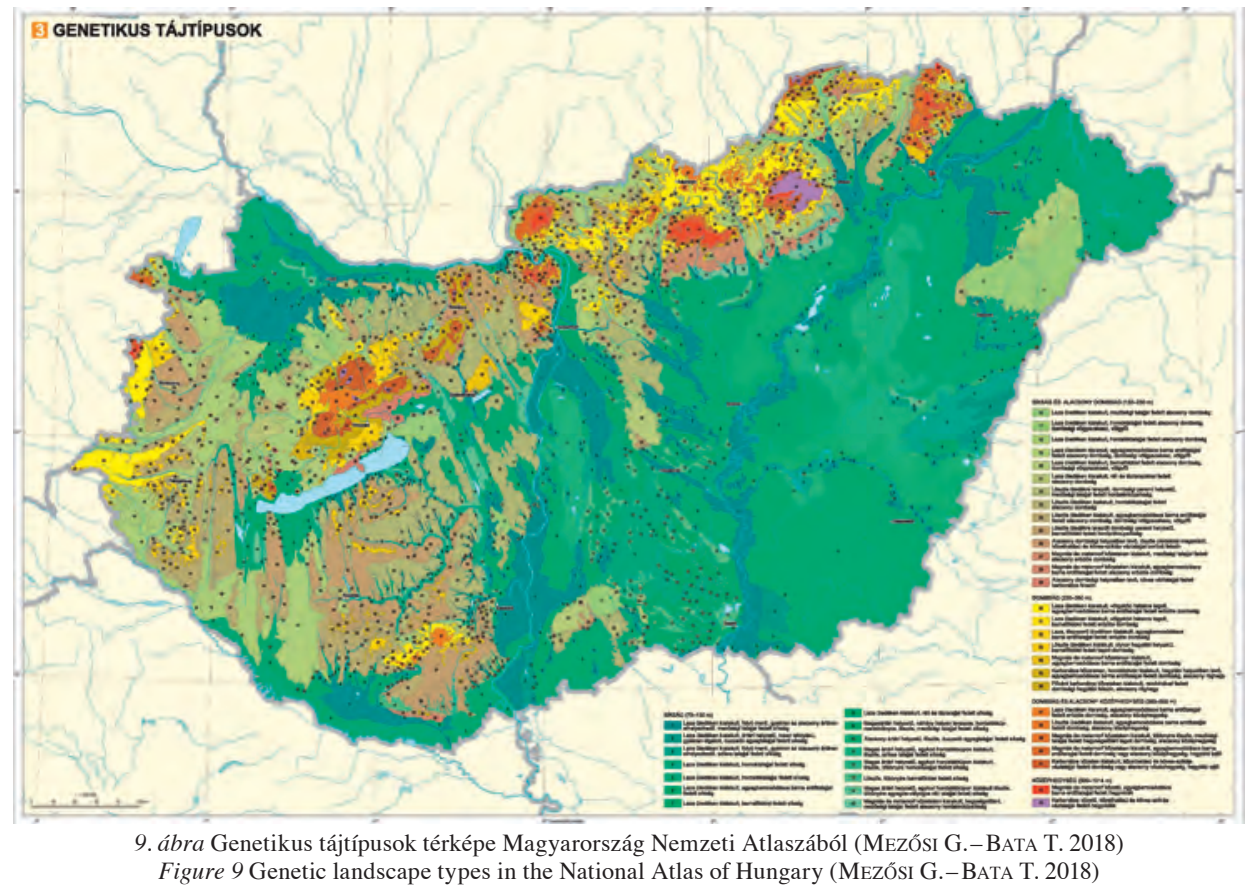


összemetszéssel alakultak ki a homogén tájtipológiai egységek. A litológiai adatok a digitálisan rendelkezésre álló agrotopográfiai információk csoportosításával, a talajok az új WRB alapú típusok összevonásával álltak elő. A számításba vett paraméterek alapján 44 eltérô típus jött létre, ami 2217, hierarchikusan tovább csoportosítható topográfiai egységet alkot.

\section{A szomszédos országok tájtipizálási módszerei, eredményei}

Szlovákia 1980-ban megjelent Nemzeti Atlasza két térkép erejéig foglalkozik a tájtipizálással. Az első térképen, amely a Természeti táj címet viseli, négy tájalkotó tényező - az éghajlat, a geomorfológiai jellemző (pl. eróziós dombság, akkumulációs síkság stb.), a talaj és az eredeti természetes növénytakaró - alapján határozták meg a tájtípusokat. A második térképnek, amely az egyes típusokat a domborzat (pl. hegyvidék, medence, síkság stb.), a településsűrűség és beépítettségi jelleg (pl. rekreációs, ipari stb.), valamint a területhasználat (pl. monokulturális erdőborítás, szántók, legelők stb.) alapján kategorizálta, a Jelenlegi tájak címet adták.

Az 1980-as évektől a MiLAN RUZIČKA, illetve MiKLós LÁSZLÓ által irányított kutatócsoport a tájökológiai térképezés elvi és módszertani kidolgozásában mutatott fel európai mintát adó eredményeket. MiKLós L. kezdeményezője és egyik szerkesztője volt a 2006-ban magyarul is kiadott Szlovákia reprezentatív geoökoszisztémáinak atlasza c. kötetnek, amelyben az ökológiai tájtipológia számos variációja (pl. az ökológiai stabilitás területi rendszere, az ökoszisztémák természetességi foka, a táji konfliktusterületek térképe stb.) szerepel.

Az 1980-as években a kárpátaljai régióban MiLleR, G. és munkatársai végeztek igen alapos terepi tájkutatási munkát, s mivel a kelet-európai zonalitás a Kárpátokban már kevésbé érvényesül, továbbá a természetföldrajzi alapokat is jóval előbb feltárták, mint pl. Podóliában, a kutatások hamar eljutottak a különféle alkalmazott tájföldrajzi célokig (10. ábra).

Az ukrán-magyar együttmúködésben készült Ukraine in Maps atlaszában (Kocsis K. et al. 2008) a tájtípusokat a horizontális, illetve vertikális zonális biogeográfiai övezetek szerint ábrázolják. A Kárpátokon belüli zónák esetében a típuselnevezés utal a domborzati

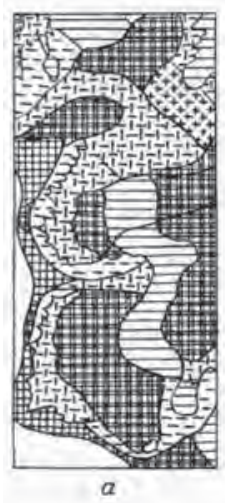

11.4 ábra Turisztikai renđeltetésii tájértékeló térképsorozat, bonitásgrafikonok lapjăn történt szerkesztéssel /11.2 és 11.3 ábrák/

Alkalmassăg: a - gyalogos turımus; b - sătorozás; c - sifutâs; d - gllesiklàs e - kilátóhely számára: I - VI bonitãsosztâlyok

10. ábra A Kárpátok egy részletének turisztikai értékminősítése (MILLER, G. 1980)

Figure 10 Landscape evaluation of a sample area in the Carpathian Mts. for touristic purpose (MILLER, G. 1980) 
és geológiai adottságra, de alapvetően a növényzeti zonalitást tükrözi, mint pl. „Korábban lomboserdőkkel fedett hegyközi medencék”, „Lomboserdők alacsony vulkáni vonulatokon”, illetve „Középhegységek füves növénytakaróval”.

A Románia Nemzeti Atlaszában (1979) található tájtípustérképet (11.ábra) igen nehezen lehet összeilleszteni a mi második nemzeti atlaszunk (1989) csaknem azonos időben készült térképével. A romániai típusalkotás következetesen csak a domborzatot és a növénytakarót veszi figyelembe, nem szerepelnek talajvízmélységre és a talajtípusra vonatkozó adatok. Példaként vessük össze a Délkeleti-Nyírségre és annak Nagykároly környéki folytatására vonatkozó típusmeghatározást. A magyarországi rész mérsékelten kontinentális félig kötött futóhomokbuckás hordalékkúpsíkság, szőlő-gyümölcsössel és részben telepített erdőkkel tagolt kultúrsztyepp, közepes és mély talajvízállással. A romániai folytatás óceanikus éghajlati hatás alatt álló löszszerú üledékekkel fedett folyó menti síkság, félig kötött homokbuckákkal tagolt mezőgazdasági terület, telepített nyárfásokkal és homokgyepekkel. A tájhatárok topográfiai lehatárolása szintén eltér, az érmelléki lösztábla déli része az országhatáron túl egy nem a fenti löszös tájtípusban folytatódik, hanem az Ér-völgy síkjában.

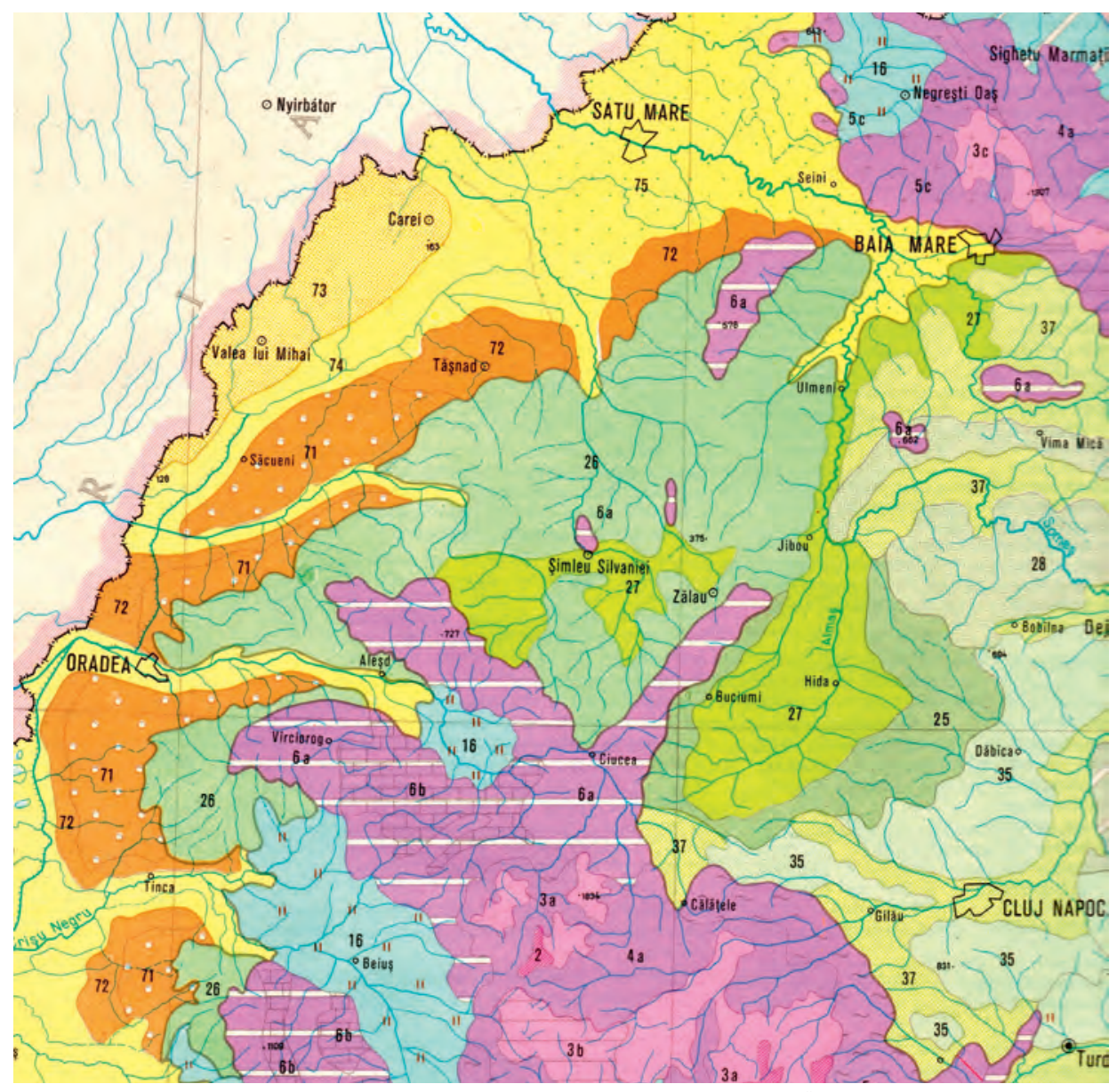

11. ábra Részlet Románia Nemzeti Atlaszának tájtípustérképéből (1979)

Figure 11 Map of the landscape types from the National Atlas of Romania (detail, 1979) 


\section{A Vajdaság tájbeosztása és tájkategóriái}

A Vajdaság tájbeosztását többtényezős komplex differenciálás alapján csupán egyetlen korábbi, a 7. ábrán látható térkép (STRÖMPL G. 1922) mutatta. A Jugoszláv Királyságban, majd a II. világháború utáni a Jugoszláviában, de Szerbia földrajzában sem készült az ország egészére vonatkozó tájbeosztás, csupán egy-egy táj, tájegyüttes elemzésére vonatkozó tanulmányok léteznek, amelyek részben érintik a Vajdaság területét is. A tájbeosztás alapját a geológiai felépítés, a domborzat, valamint a talajtípusok képezik. Ugyanakkor MATVEJEV, S. D. (1973) az egész országra vonatkozó tájelemzése kapcsán eredeti sztyeppfoltokkal, azaz biogeográfiai meghatározottsággal jellemezi a Vajdaság területének nagy részét.

A Vajdaság első részletes tájbeosztásának elkészítésére NAGY I. és munkatársai vállalkoztak (2018). A munka alapját a 2012-es CORINE adatbázis, a talajtérkép, valamint a 30 m-es felbontású domborzati (DEM) modell képezte. Az említett térképeknek a Vajdaság határaihoz való igazításával (kivágással) és kombinálásával ArcGIS és ArcMap programban lehetôvé vált az egyes tájegységek közötti határok meghatározása. A fotointerpretációs területhasználati térképen jól elhatárolhatók az erdős területek, az urbánus és vízfelületek. A domborzati múholdfelvétel alapján jól megfigyelhetők a magassági különbségek, árnyékolással és színskála alkalmazásával kirajzolódnak a geomorfológiai formák. A talajtérkép kis mértékben generalizált, de a talajtípusok követik a hozzájuk kapcsolódó domborzati formák határait és elhelyezkedését.

Bár a Vajdaság túlnyomórészt sík terület, tájszerkezetének változatosságát mégis a jól érzékelhető földtani és domborzati különbségek határozzák meg: a két jelentősebb domborzati egység - Verseci-hegy 641 m, Tarcal (Fruška Gora) 539 m - mellett külön tájegységet képeznek a löszhátak, az ősfolyóhálózat által lepusztított löszfelületek (teraszok), valamint a hátságokra telepedett, relatíve magasabb homokvidékek (SzabadkaHorgosi-homokvidék, Delibláti-homokpuszta). A három nagy folyó (Duna, Tisza, Száva), alluviális lapályai képezik a domborzat legalacsonyabb felszínformáit (morotvák, helyenként mocsaras felszínek, árterek). A talajok domborzati formákat követő változatos térbeli elrendeződése és az évszázadok óta uralkodó agrártevékenység agrártájtípusok (szántógazdálkodás, legeltető gazdálkodás, szőlő-gyümölcstermesztés, erdőgazdálkodás) kialakítását eredményezte. A további antropogén tájformáló tényezők közül a települési, városi és ipari területeknek, valamint az infrastruktúra-hálózatoknak (úthálózat, DunaTisza-Duna-csatornarendszer) van helyenként lényeges tájformáló szerepe. Az elvégzett elemzés alapján a 12. ábrán láthatók a tájbeosztás jellemző egységei. A főbb egységeken túl valamennyi tájtípus keretében további differenciálására is sor került. (Megjegyzendő, hogy az ábrán feltüntetett nagytáj és középtáj taxonómiai szintek eltérnek a Magyarország Nemzeti Atlaszában [2018] használt beosztástól. Az itt nagytájnak nevezett tájegységek a Nemzeti Atlaszban középtájak, az itt felsorolt középtájak pedig kistájaknak felelnek meg.)

\section{Történeti tájtipizálás}

A táj földrajzi vizsgálatához a tudományos értelmezések kezdetétől hozzákapcsolódott az időbeliség. Mióta a társadalom a természeti környezetet rendszerként, azaz tájként értelmezi (akár a mindennapi élethez, akár a mélyebb tudományos megismeréshez), önmagát és tevékenységének hatását nem hagyhatja ki ebből a rendszerből. A természet és az emberi tevékenység kölcsönhatásának összefüggése talán a legfontosabb táji összetevő az emberi kultúrák számára, leginkább azért, mert összeköti a különböző korok társadalmát, mivel 


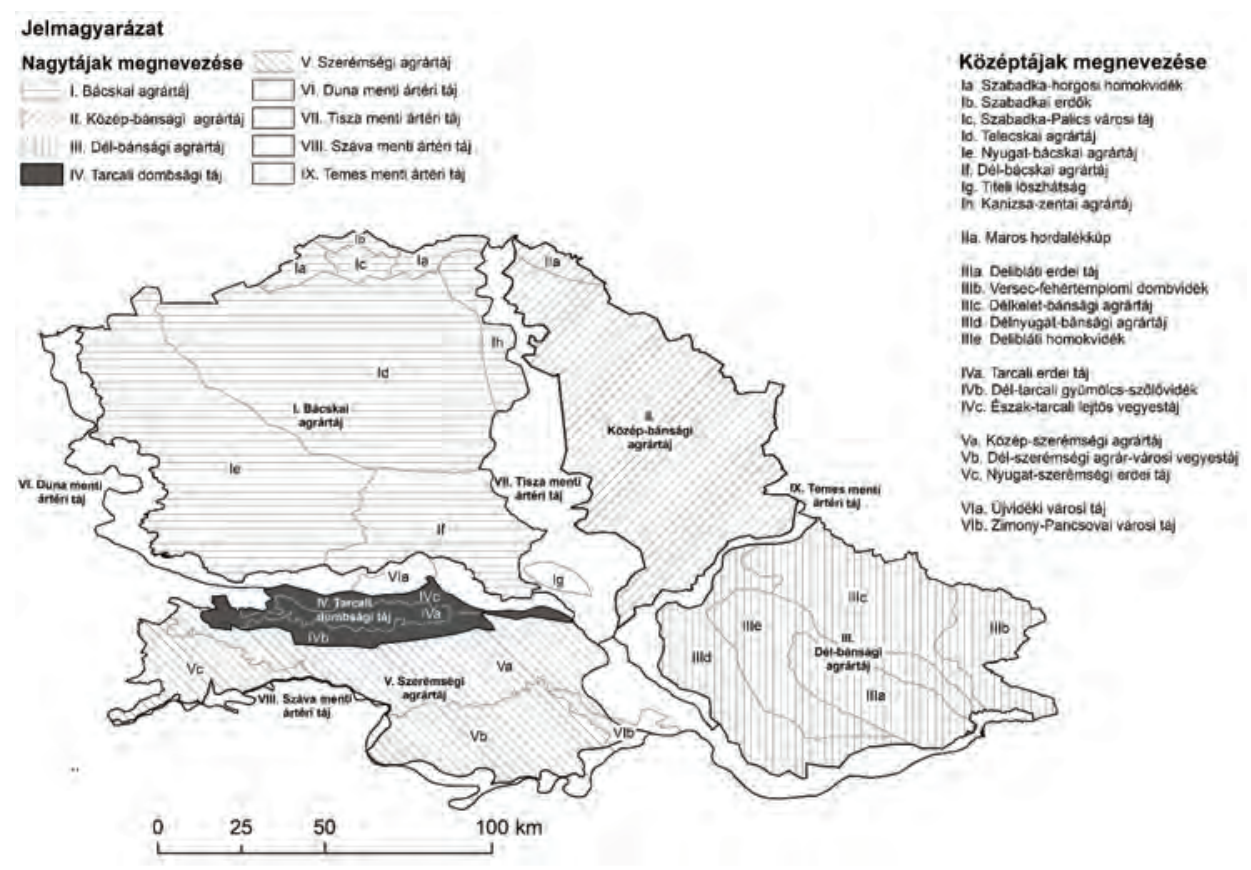

12. ábra A Vajdaság tájtípusai (szerk. NAĐ, I. et al. 2018)

Figure 12 Landscape types of Vojvodina/Serbia (eds. by NAĐ, I. et al. 2018)

a korábbi társadalmak tevékenységének számos nyoma megtalálható a későbbi tájban. Ez a gondolat már a 20. század elején megfogalmazódott az emberföldrajzon belül, majd a 20. század második felében egyre több tudomány fordult a táj történetiségének vizsgálata felé. A néprajz mellett a történettudomány új irányzata, a történeti ökológia elemzi sokoldalúan az ember és a környezet történeti korokra vonatkozó kapcsolatát. Az ezredforduló után egyre inkább kiteljesedő tájrégészet szoros kapcsolatot jelent a földrajz és a régészet között. Az elmúlt két évtizedben a történeti tájvizsgálatba bevonható források és módszerek is folyamatosan bővültek. Az egyik jelentős forrás maga a természeti környezet, mivel a földrajzi környezet egyes elemei az emberi társadalom történeti időszakában változatlannak tekinthetők. Ilyenek a makrodomborzati, geológiai, alapvízrajzi sajátosságok, valamint a földrajzi övezetességgel összefüggő zonális éghajlati, növényzeti, talajtani, vízjárási jellemzők. Ugyanakkor a táj sok eleme a természeti folyamatok révén folyamatosan változik, elsôsorban az éghajlat különböző jellegú és periódusú váltakozásának van hatása a felszínfejlődési folyamatokra és ezzel összefüggésben a talajra, vízrajzra, a növény- és állatvilágra. Ezeknek az alapvető és változó tájalkotóknak a természettudományok modern eljárásaival végzett vizsgálati eredményei jól használhatók a táj történeti vizsgálatában, fontos forrásadatok a tájak adott korra vonatkozó rekonstrukcióiban, illetve változási folyamatok értelmezésében.

A források másik nagy csoportja a társadalmak tájformálásához kapcsolódik, hiszen a természeti adott korszakbeli állapotát egyre jelentősebben befolyásolta a bővülő emberi, társadalmi tevékenység, összefüggésben a népességszám növekedésével, a társadalmi gazdasági fejlődéssel, a természeti táj „,belakásával”, tájhasználatával, amelynek következtében a tájak egyre erôteljesebb mértékben kultúrtájakká alakultak. A tájak történeti állapotára - mind a természeti, mind a kultúrtáji jellemzőkre - vonatkozó források között jelentősek 
a különböző írásos emlékek, amelyek a Kárpát-medencében a római kortól használhatók, de a 11. századtól egyre bővülő adatbázist jelentenek, elsősorban a népességre, településekre, vízrajzra, határhasználatra, utakra és éghajlati jellemzőkre tartalmaznak fontos információkat. A 17-18. századtól pedig a különböző jellegú térképmúvek adnak fontos támpontokat a tájak vízrajzára, településhálózatára és felszínfedettségére. A történeti tájhasználatra utaló néprajzi tárgyi anyagok mellett az utóbbi két évtizedben jelentôssé váltak a régészeti források is a történeti korok tájrekonstrukcióiban. A kapcsolat a régészet és a tájtudományok között kölcsönös, hiszen a régészeti leletek fontosak a táj történeti értelmezésben, míg a táj földrajzi rekonstrukciója, elemzése sokat segít a régészeti összefüggések kibontásában. A történeti tájak vizsgálatában, tipizálásában az írott források mellett komoly szerepe lett a geoinformatikai (GIS) módszerek alkalmazásának. A különböző források adatbázisainak digitalizálása és térinformatikai feldolgozása jelentősen kitágította a térbeli elemzések és ábrázolások lehetôségét és egyben a távérzékelési adatok (pl. légi- és ürfelvételek) forrásként való bevonását is.

Európában a történelmi tájak kutatása igen elterjedt, bár jelentős különbségek vannak a témákban és módszerekben, hiszen olyan kutatási területről van szó, amelyben igen sok tudomány érintett. Ennek következtében igen különböző eredmények születnek, pl. a tájképi rekonstrukciók mellett történeti vízrajzi elemzések, éghajlati rekonstrukciók, vagy éppen komplex tájrégészeti monográfiák. A sokféle megközelítésből három fő irányzat emelhető ki: egyrészt adott tájak egy jellemző korszakának részletes feldolgozása, másrészt egy táj több történeti koron átívelő változásának elemzése, harmadsorban pedig egy nagyobb regionális egység, vagy egy országterület egészére vonatkozó tájtípusalkotás egy meghatározó történeti korszakra vonatkozóan.

Egyre több országban készül egy-egy tájra, elsősorban az utóbbi 300 év időszakára vonatkozó tájrekonstrukció, hiszen ez az időszak, ami alatt igen sokat változott a táj, és a források is nagyobb mértékben állnak rendelkezésre, mint a korábbi korszakokra vonatkozóan. A tájtípusképzés terén leginkább az angol tájkarakterprogramban jelenik meg a történeti jelleg, de elsősorban mint egy jelentős tájkaraktertípus alkotó tényezője, azaz nem cél az önálló történeti tájtipizálás. Ebből fejlődött ki a történeti tájak jellemzése program (Historical Landscape Characterisation, HCL), Alapjában véve egyes védett tájakra, megyékre készültek, szoros összefüggésben a környezet- és tájvédelemmel, de - szemben például Magyarországgal - a védettségben, területi tervezésben elsődleges tényező a történeti karakter (13. ábra). A HLC programhoz kapcsolódik a Historical Land-use Assessment project (HLA), amely történeti földhasználatot rögzíti (http://hlamap.org.uk/).

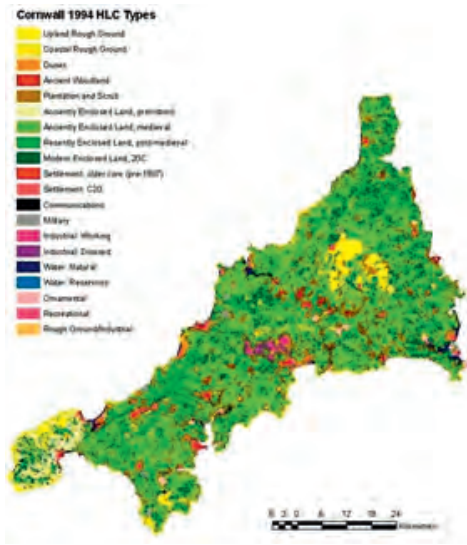

13. ábra A Cornwall-félsziget (Nagy-Britannia) történeti tájkarakter (HLC) térképe. Forrás: https://historicengland.org.uk/research/methods/ characterisation-2/historic-landscape-characterisation/

Figure 13 Historical landscape character map of Cornwall (Great Britain) 
Magyarországon - ha nem is központi program alapján, hanem elsősorban egyes kutatómúhelyek jóvoltából - már készülttek történeti tájakról tájhasználati rekonstrukciók. Ezek többsége a 18-19. századi katonai térképek felszínfedettségének elemzésére épül, ugyanakkor vannak korábbi időszakra, pl. a középkori tájakra vonatkozó munkák is (pl. PINKE Zs. 2010). A 20. század végén készült az első, a mai országterületre vonatkozó történeti tájtípustérkép (SoMOGYi S. 1996). A szerző történeti korszakként a honfoglalás időszakát választotta. Elsősorban a természeti-táji környezet rekonstrukcióját dolgozta ki a domborzati helyzet, vízrajzi jellemzők, a talajtípusok és a jellemző (az éghajlati különbségeket is kifejezô) növénytársulások alapján. Három fő domborzati csoporton belül (síkság, dombság és hegység) 10 altípust alakított ki (14.ábra). Ugyanakkor a munka készülésének idôszakában kénytelen volt csak a jelenlegi országhatáron belüli területre szorítkozni.

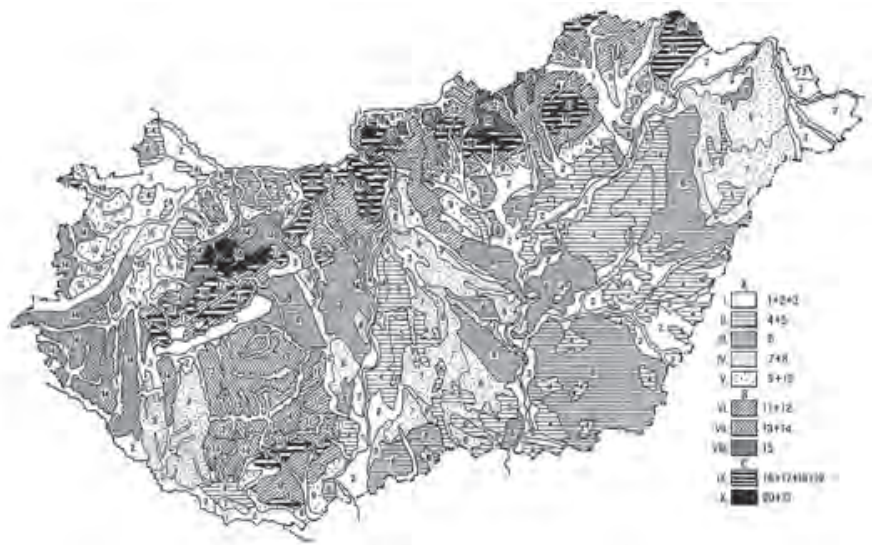

14. ábra A mai országterület honfoglalás kori rekonstruált tájtípustérképe (SomOGYi S. 1996). A részletes jelmagyarázatot lásd az idézett tanulmányban.

Figure 14 Reconstruction of the landscape types during the Hungarian conquest, $10^{\text {th }}$ century (SOMOGYI, S. 1966). Detailed legend see in the original paper.

Az elmúlt években a Magyar Nemzeti Atlasz tájfejezetéhez elkészült a történeti Magyarország teljes területére vonatkozóan a Kárpát-medence történeti tájtípusainak térképe (15. ábra), mégpedig egy hosszabb összefüggő korszakra, a 11-16. század közötti időszakra vonatkozóan, az előző múhöz hasonlóan generalizált formában, de összetettebb szempontrendszer alapján, a kultúrtáj állapotában lévő különbségeket is megjelenítve. A tájtípusok kialakítása során - a felhasználható különböző földrajzi, írásos és régészeti forrásanyag alapján - egyrészt a domborzati helyzet, a domborzati tagoltság mértéke, a meghatározó felszíni kőzetek típusa, az uralkodó talajtípusok, az eredeti növénytakaró jellegzetes társulásai és a vízrajzi állapot, másrészt az adottságokra épülő tájhasználat (a megtelepülés mértéke, jellege, a településsűrűség és a jellemző határhasználati formák) voltak a típusképzés fő szempontjai, illetve ezen túl a kultúrtáji átalakulás mértéke (nincs jelen, gyenge, közepes, vagy erős kultúrtáj formálás) volt még típus- és altípusképző tényező.

\section{Összefoglalás}

A tájtipizálás a tájkutatás hagyományos témája és fontos elméleti szakterülete. A klasszikus tipizálási módszerek esetében a típusképző tényezőtöbbnyire a domborzat, a természetes növényzet és a földhasználat, beleértve a beépítettséget is. A domborzatra koncentráló 


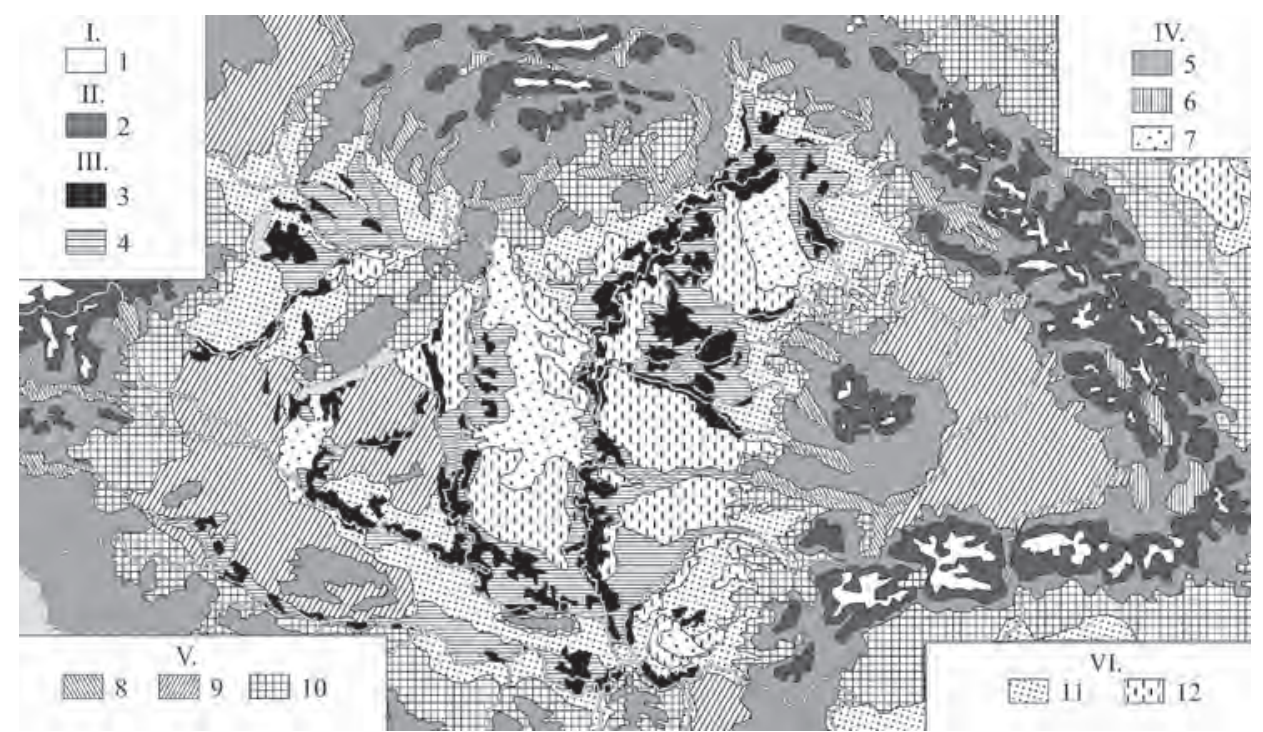

15. ábra A Kárpát-medence történeti tájtípusai és a kultúrtáj állapota a 11. és 16. század között (CsüLLöG G. et al. 2014). A részletes jelmagyarázatot lásd az idézett tanulmányban.

Figure 15 Historical landscape types and the condition of the cultural landscape in the Carpathian Basin, between the $11^{\text {th }}$ and $16^{\text {th }}$ centuries (CsüLlÖG, G. et al. 2014). Detailed legend see in the original paper.

tájtipizálásból születtek a felszínalaktani (geomorfológiai) tájtípustérképek. Az eredeti növénytakaró rekonstruálásával készültek a növényföldrajzi tájbeosztások. Az aktuális földhasználat, valamint a beépítés jellege pedig a társadalomföldrajzi környezetszemlélet számára dolgozott ki jól használható tájtípus-meghatározásokat (pl. montanogén, indusztrogén, agrogén, urbanogén stb. tájtípusok).

A földrajzi tájtipizálás többnyire arra törekedett, hogy a tájalkotó tényezők közül minél több szerepeljen az egyes tájtípusok definiálásában. A típusmegnevezés tehát „,mondjon valamit" az adott terület domborzatáról, éghajlati és vízrajzi adottságairól, de a talajáról, a földhasználatáról és a beépítettségéről is.

Az európai országokban leginkább az 1960-as években készültek tájtípustérképek. Egységes európai metodika nem alakult ki, sôt az adott ország természeti adottságaihoz igazodva más és más tájalkotó tényezőre helyezték a hangsúlyt. A skandináv országokban az éghajlatnak, a Brit-szigeteken a geológiai felépítésnek, Kelet-Európában az életföldrajzi övezetességnek tulajdonítottak erős tájtípusformáló hatást. Magyarországon a közép-európai,főként német geomorfológiai iskolák nyomában haladva készültek tájtípusrendszerek, amelyek típusmegnevezései azonban alig illeszthetők össze az országhatáron túli folytatásukra alkalmazott szlovákiai, romániai stb. meghatározásokkal.

Az 1980-as évek végére egyértelmúvé vált, hogy a sok természetföldrajzi résztulajdonságból felépített típusmegnevezés túlságosan általános kategóriákat eredményez, ami végül is egyetlen szakterület információigényét sem elégíti ki, tehát csupán tájékoztató jellegú eredményt hozhat és nem használható pl. hatósági döntések, vagy tervezési munkák számára. Ezért nem véletlen, hogy több gyakorlati szakterület nem használta a földrajzi tájtipológiai kategóriákat, hanem kidolgozta a saját tájtipizálási rendszerét. MAJER A. (1963) pl. meghatározta a legfontosabb erdészeti tájtípusokat, ami az erdôtelepítés szempontjából fontos domborzat-mikroklíma-talaj tényezőhármasra épül. Ennek megfelelően van például dombsági vastag termőrétegú barna erdőtalajú tölgyes erdészeti tájtípus, 
vagy homokos talajú ártéri keményfás ligeterdő tájtípus. A tájépítészek hagyományosan három fó ún. tervezési tájtípust; termelőtájakat, lakótájakat és üdülőtájat különítenek el (Mő́csÉnyi M. 1967, Csima P. 2008). Az ökológiai tájkutatás 1980-as években lezajlott kibontakozása magával hozta a tájökológiai típusalkotást is, amelyben természetesen az aktuális élővilág áll a tipológia középpontjában. Ez azt jelenti, hogy a klasszikus földrajzi tájtipizálással szemben a másodlagos és a kultúrnövényzet egyenrangú szerepet játszik az egykori természetes (potenciális) növényzettel, másrészt sokkal nagyobb szerepet kap az élővilág múködését befolyásoló tájszerkezet, például a fragmentáció mértéke, a tájmintázat, a szomszédsági peremhatás, illetve a védettségi kategóriák topográfiai elrendeződése, a pufferövezetek kiterjedése.

Az Európai Unió létrejöttével felerősödött az igény egy európai szintü tájtipizálási rendszer megalkotására. Jelentős módszertani előrelépés volt a távérzékelési adatok széleskörú felhasználása, valamint a típusokhoz rendelt ,-tól-ig” kategóriák automatikus, statisztikai lehatárolása, pl. a természetes töréspontos módszer alkalmazása. A próbálkozások azonban ezúttal is inkább speciális szempontokat szem előtt tartó, célirányos tipológiai rendszert eredményeztek, és az is beigazolódott, hogy a speciális célokon túl a méretarány is lényegesen befolyásolja a tipológiai rendszer felépítését.

Jelenleg az Európai Táj Egyezmény és a nemzetközi tájkarakter-kutatások hatására létrejött Magyarország Nemzeti Tájstratégiájában körvonalazott feladatok teljesítése ad munkát a hazai geográfiának (CSORBA P. et al. 2017). Ezzel párhuzamosan az új Magyar Nemzeti Atlasz (2018) jó példáihoz (pl. a WRB talajosztályozási térkép) hasonlóan törekedni kell a teljes Kárpát-medencét bemutató tájtípustérkép elkészítésére.

CSORBA PÉTER

DE TTK Tájvédelmi és Környezetföldrajzi Tanszék, Debrecen

csorba.peter@science.unideb.hu

NAGY IMRE

Újvidéki Egyetem Földrajztudományi Tanszék, Újvidék

KE Gazdaságtudományi Kar, Kaposvár

nagyi@rkk.hu

CSÜLlÖG GÁBOR

ELTE TTK Környezet- és Tájföldrajzi Tanszék, Budapest

g.csullog@gmail.com

\section{IRODALOM}

Antrop, M.-Belayew, D.-Droeven, E.-Feltz, C.-Kummert, M.-Van Eetvelde, V. 2004: Landscape research in Belgium. - Belgeo 5. 2-3. pp. 199-208.

Atlas de France-RECLUS 2005: UMR ESPACE. - GDR Libergéo, Paris.

Csima P. 2008: Tájvédelmi szabályozás a településrendezési tervekben. - In: CsorbA P.-FAzEKAs I. (szerk.): Tájkutatás - Tájökológia. Meridián Alapítvány Debrecen, pp. 401-408.

CsORBA P. 2013: Tájföldrajz. - In: GÁBRIs Gy. (szerk.): Általános természeti földrajz. Eötvös Kiadó, Budapest, pp. 442-466.

Csorba P. 2015: Az új nemzeti atlasz tájföldrajzi fejezetének múhelymunkái. - In: KóKAI S.-Boros L. (szerk.): Tiszteletkötet Dr. Gál András geográfus 60. születésnapjára. Nyíregyháza-Szerencs, pp. 159-169.

Csorba P.-PÁdÁRnÉ TÖRÖK É.-KinCSEs K. 2017: Megjelent a Nemzeti Tájstratégia (2017-2026) kormányhatározat. - Földrajzi Közlemények 141. 4. pp. 399-406.

CsÜLLÖG G.-FRISNYÁK S.-TAMÁs L. 2014: Történeti tájtípusok a Kárpát-medencében (11-16. század). - Történeti Földrajzi Közlemények 2. 1-2. pp. 1-10. 
De Grote Bosatlas 1988. - Wolters-Noordhoff Atlasprodukties, Groningen. 207 p.

HAAREN, vON CH.-ALBERT, CH. (szerk.) 2016: Ökosystemleistungen in ländlichen Räumen. Grundlage für menschliches Wohlergehen und nachhaltige wirtschaftliche Entwicklung. - Naturkapital. Hannover-Leipzig. 58 p.

HaAse, G. 1976: Die Arealstruktur chorischer Naturräume. - Petermanns Geographische Mitteilungen 120. 2. pp. 130-135.

JANSSON, U.-MAANDI, P.-QviströM, M. 2004: Landscape research in Sweden. - Belgeo 5. 2-3. pp. 361-368.

Kocsis K.-Rudenko, L.-Schweitzer F. (szerk.) 2008: Ukraine in Maps. - Kyiv-Budapest. 147 p.

Kocsis K. (főszerk.) 2018: Magyarország nemzeti atlasza. Természeti környezet. - MTA CSFK Földrajztudományi Intézet, Budapest. 187 p.

MAJER A. 1963: Erdő- és termőhelytípusok útmutató növényei. - Országos Erdészeti Főigazgatóság Budapest. $326 \mathrm{p}$.

MANNSFELD, K. 1984: Intensitätsstufen der geochorologischen Erkundung. - Umweltforschung, Gotha. pp. 63-79. Matvejev, S. D. 1973: Predeli Jugoslavije i njihov živi svet. - Naučna Knjiga, Beograd.

MeEus, J. H. A. 1995: Pan-European landscapes. - Landscape and Urban Planning, 31. 1-3. pp. 57-79.

MikLós L.-IZAKOvičovA Z. 2006: Szlovákia reprezentatív geoökoszisztémáinak atlasza.-Szlovák Tudományos Akadémia Ökológiai Intézet, Banska $\square$ iavnica. 123 p.

Miller, G. P. 1980: A hegyvidéki és hegylábi területek tájkutatása. - MTA Földrajztudományi Kutatóintézet, Budapest. $185 \mathrm{p}$.

Mő́CSÉNYI M. 1968: A táj és a zöldterület fogalmi problémái a tájrendezés nézőpontjából. - Településtudományi Közlemények 17. 21. pp. 66-76.

NaĐ, I.-Stojanović, V.-Mesaroš, M.-Fekete, R. 2018: Predeona tipizacija Vojvodine (Kísérletek a Vajdaság tájbeosztásának definiálására), - Kézirat. Zbornik radova, Novi Sad, DGTH PMF.

NAGY I. 2007: A természeti adottságok, erőforrások és a környezet állapota. - In: NAGY I. (szerk.): Vajdaság. A Kárpát-medence régiói 7. MTA Regionális Kutatások Központja - Dialóg Campus Kiadó, BudapestPécs. 575 p.

NEEF, E. 1963: Die theoretischen Grundlagen der Landschaftslehre. - Haack VEB, Gotha. 152 p.

PINkE Zs. 2010: A középkori Hortobágy-Sárrét település- és természetföldrajzához III. - In: SzILASSI P.-HENITS L. (szerk.) Tájváltozás értékelési módszerei a XXI. században. Földrajzi tanulmányok 5. Szeged,pp. 303-315.

Popov, D.-Marković, S.-Jovanović, M.-Mesaroš, M.-Arsenović, D.-Stankov, U.-Gubik, D. 2012: Geomorphological investigations and GIS approach of the Tami $\square$ oess plateau, Banat Region (Northern Serbia). - Geographica Pannonica 16. 1. pp. 1-9.

SomogYi S. 1996: A honfoglalás földrajzi környezete és annak átalakulása. - Földrajzi Közlemények 120. 2-3. pp. 111-118.

STRÖMPL G. 1922: Tájtípusok. - In: BÁTKY Zs.-KogutowiCZ K. (szerk.): Kogutowicz Zsebatlasza az 1922, évre. A Magyar Néprajzi Társaság Emberföldrajzi Szakosztályának kiadása. Budapest.

SzocsavA, V. B. 1970: Topologija sztyepüh geoszisztem. - Nauka, Moszkva.

SwAnwick, C. and Land Use Consultants 2002: Landscape character assessment guidance for England and Scotland. - Countryside Agency and Scottish Natural Heritage. 84 p.

Trochet, J-R. 2004: L'etude des paysages en France. Eléments d'histoire. - Belgeo 5. 2-3. pp. 257-264. 